\title{
Development of SCAR Primers for PCR Assay to Detect Diplodia seriata
}

\author{
M. T. Martín, M. J. Cuesta, and L. Martín \\ Instituto Tecnológico Agrario de Castilla y León-Zamadueñas, Carretera de Burgos Km 119, 47071 Valladolid, Spain \\ Correspondence should be addressed to M. T. Martín; mtmvillullas@gmail.com
}

Received 28 April 2014; Revised 8 July 2014; Accepted 9 July 2014; Published 28 September 2014

Academic Editor: Giampiero Valè

Copyright (C) 2014 M. T. Martín et al. This is an open access article distributed under the Creative Commons Attribution License, which permits unrestricted use, distribution, and reproduction in any medium, provided the original work is properly cited.

\begin{abstract}
The aim of this study was to develop primer pairs for Diplodia seriata identification, one of the most common fungal species associated with grapevine decline in Castilla y León (Spain). Genetic variability of selected isolates of D. seriata was estimated. A molecular marker was generated from a random amplified polymorphic DNA (RAPD) fragment. PCR products of around $1200 \mathrm{bp}$ were obtained with OPE20 primer. The PCR products were cloned and sequenced. The sequences were compared and a fragment of $1207 \mathrm{bp}$ was used to design primer pairs. Two primer pairs were selected (DS3.8 S3-DS3.8 R6 and DS3.8 S3-DS3.8 R4) that amplified a single DNA product of $634 \mathrm{bp}$ and $233 \mathrm{bp}$, respectively, with $D$. seriata isolates. No amplification was obtained for any of the 57 isolates of other species. The designed SCAR primer pairs allowed a rapid detection of $D$. seriata, and were able to detect $0.1 \mathrm{pg}$ of the target DNA. Detection was specific and sensitive for $D$. seriata. The established protocols detected these fungi in naturally infected grapevines after DNA purification. Diplodia seriata was detectable without DNA purification and isolation in $62.5 \%$ to $75 \%$ of reactions. The detection of this pathogen in wood samples has great potential for use in pathogen-free certification schemes.
\end{abstract}

\section{Introduction}

Grapevine decline causes serious economic losses to the wine industry worldwide [1]. Among the numerous fungi associated with grapevine decline, species of Botryosphaeriaceae are dominant $[2,3]$. They are well known as pathogens, saprophytes, and endophytes on a wide range of woody angiosperm and gymnosperm hosts $[4,5]$.

Identification of Botryosphaeriaceae spp. based on morphological characteristics remains a difficult task; therefore molecular sequence data and phylogenetic analysis are commonly used to confirm identifications [6-8]. Using these methods numerous species of Botryosphaeriaceae spp. have been identified and associated with grapevine decline worldwide, for instance, Diplodia seriata, D. mutila, Botryosphaeria dothidea, Neofusicoccum parvum, N. mediterraneum, N. australe, N. ribis, N. luteum, Lasiodiplodia theobromae, L. crassipora, D. viticola (Spencermartinsia viticola), Dothiorella sarmentorum, and $D$. iberica $[1,4,5]$. The development of restriction digest patterns following PCR amplification of the rDNA region has permitted the identification and detection of some Botryosphaeriaceae spp. [9]. Botryosphaeriaceae spp. were also identified based on sequencing of the ITS region although this sequence was not always sufficient to identify all species and sequences of other genes such as the elongation factor 1-alpha and beta tubulin which were required. These methods require the isolation of the fungi before DNA extraction and continue to be time-consuming and expensive.

Over the last two decades, newly established vineyards in Castilla y León (Spain) have shown an increasing percentage of plants with symptoms of wood decline. Research efforts allowed us to analyse grapevine samples from cankered and asymptomatic young and adult plants. Molecular methods were used to confirm the identification of $D$. seriata, which was one of the most abundant species found [2].

Molecular markers may be helpful in investigating numerous aspects of grapevine decline that still remain unclear, such as disease aetiology, epidemiology, taxonomy of the putative causal agents, and their genetic variability, and in improving diagnostic tools. In particular, random amplified polymorphic DNA (RAPD) markers were largely used for studying genetic variation in species such as Erysiphe graminis [10] and Uncinula necator [11]. RAPD markers were 
easy to perform and low in cost and no prior knowledge of the genome being investigated was required. RAPD markers also allowed the development of sequence characterised amplified region (SCAR) specific primer pairs, such as was published for Monilinia spp. [12] and Agrobacterium vitis [13]. In the case of grapevine decline Pollastro et al. [14] proposed SCAR primer pairs for the identification of Fomitiporia mediterranea and Phaeomoniella chlamydospora associated with esca and Phomopsis viticola, the causal agent of Phomopsis cane and leaf spot. Lardner et al. [15] published SCAR primers capable of amplifying DNA of Eutypa lata, the main causing agent of Eutypa dieback. The purpose of the present study was to develop SCAR specific primers, which could be used in conventional PCR to detect D. seriata.

\section{Materials and Methods}

2.1. Sample Analysis and Fungal Isolates. Fungi associated with grapevine decline were obtained from 381 vines. Fifty percent of the isolates were from Castilla y León, $47 \%$ from other Spanish regions, and 3\% from other countries. Seventy-three percent were mature vine ( $>5$ years). Sixty-four percent were grapevine branches. External symptoms were esca (22\%), Eutypa dieback (34\%), Petri disease/black food disease $2 \%$, asymptomatic vines (19\%), and others (23\%). This study included $47 \mathrm{D}$. seriata. Fifty-seven isolates of other species were used as controls. Tables 1(a) and 1(b) show the isolates' names and where they were obtained. Eleven cultures were obtained from the Centraalbureau voor Schimmelcultures (CBS Fungal Collection, Utrecht, The Netherlands), Eutypella citricola (810) was a kind gift from Dr. J. Luque (IRTA, Barcelona, Spain). All isolates were grown on potato dextrose agar (PDA) (Merck, Darmstadt, Germany) at $25^{\circ} \mathrm{C}$ in darkness. Fungal isolation, morphological and molecular identification, restriction patterns, DNA sequencing, and sequence analysis were done [2].

2.2. Extraction and Purification of DNA. For rapid detection, fungi grapevine genomic DNA was extracted using Redextract-N-Amp plant PCR kit (Sigma, St. Louis, MO, USA) following the manufacturer's instructions.

Genomic DNA was purified from mycelium using the DNeasy plant minikit (QIAGEN, Cologne, Germany). All DNA samples were diluted to a working concentration of $10 \mathrm{ng} / \mu \mathrm{L}$.

\subsection{Development of SCAR Markers}

2.3.1. RAPD Amplification. The PCR reaction mix was prepared following the commercial recommendation of Illustra GE Healthcare puReTaq Ready-To-Go PCR Beads (Amersham, Buckinghamshire, UK) supplemented with $1 \mathrm{mM}$ of $\mathrm{MgCl}_{2}$ as described by [16], $0.7 \mu \mathrm{M}$ of primer, and $50 \mathrm{ng}$ of DNA template in a final volume of $25 \mu \mathrm{L}$. The PCR reaction was run according to [17]. Each run included as control a reaction without DNA. Each primer-template combination was tested at least twice. PCR amplifications were performed using a Gene Amp 7200 thermocycler (Applied Biosystems,
TABLE 1: (a) Forty-seven isolates of Diplodia seriata used in this study. Isolates used in RAPD analysis are shown in bold. Eleven $D$. seriata isolates $(*)$ were used for cloning essays. (b) Fifty-seven isolates used as control in this study. Isolates used in RAPD analysis are shown in bold.

(a)

\begin{tabular}{|c|c|c|}
\hline Species & Strain & Location \\
\hline Diplodia seriata & CBS719.85c & New Zealand \\
\hline D. seriata & ${ }^{*}$ Napa-c & California, USA \\
\hline D. seriata & ${ }^{*}$ CBS112555a & Portugal \\
\hline D. seriata & ${ }^{*} Y 46-1-1 b$ & Cigales, Spain \\
\hline D. seriata & Y46-8-1b & Cigales, Spain \\
\hline D. seriata & ${ }^{*}$ Y62-1-1c & Arribes, Spain \\
\hline D. seriata & Y63-4-1b & Arribes, Spain \\
\hline D. seriata & ${ }^{*}$ Y79-4-3a & Ribera del Duero, Spain \\
\hline D. seriata & Y84-1-1a & Toro, Spain \\
\hline D. seriata & Y87-3-1c & Arribes, Spain \\
\hline D. seriata & Y87-8-1a & Arribes, Spain \\
\hline D. seriata & ${ }^{*}$ Y90-10-1a & Navarra, Spain \\
\hline D. seriata & Y103-3-3b & Extremadura, Spain \\
\hline D. seriata & ${ }^{*} \mathrm{Y} 103-4-3 \mathrm{a}$ & Extremadura, Spain \\
\hline D. seriata & Y111-27-1 & Arribes, Spain \\
\hline D. seriata & ${ }^{*} \mathrm{Y} 112-24-1 \mathrm{a}$ & Arribes, Spain \\
\hline D. seriata & ${ }^{*} \mathrm{Y} 116-10-1 \mathrm{a}$ & Arribes, Spain \\
\hline D. seriata & Y116-27-96 & Arribes, Spain \\
\hline D. seriata & Y121-15-4 & Arribes, Spain \\
\hline D. seriata & Y122-44-91 & Arribes, Spain \\
\hline D. seriata & Y125-12-1b & Arribes, Spain \\
\hline D. seriata & Y126-73-91 & Arribes, Spain \\
\hline D. seriata & Y126-83-91 & Arribes, Spain \\
\hline D. seriata & Y128-3-1b & Galicia, Spain \\
\hline D. seriata & Y161-1-1 & Alicante, Spain \\
\hline D. seriata & Y163-11-1 & Alicante, Spain \\
\hline D. seriata & Y163-13-1a & Alicante, Spain \\
\hline D. seriata & Y168-21-1b & Alicante, Spain \\
\hline D. seriata & Y169-11-1 & Alicante, Spain \\
\hline D. seriata & Y169-18-1 & Alicante, Spain \\
\hline D. seriata & Y169-18-2 & Alicante, Spain \\
\hline D. seriata & Y170-8-1 & Alicante, Spain \\
\hline D. seriata & Y171-3-1 & Alicante, Spain \\
\hline D. seriata & Y172-12-1 & Alicante, Spain \\
\hline D. seriata & Y172-19-3 & Alicante, Spain \\
\hline D. seriata & Y173-14-1 & Alicante, Spain \\
\hline D. seriata & Y173-17-1 & Alicante, Spain \\
\hline D. seriata & Y178-1-1 & La Rioja, Spain \\
\hline D. seriata & Y178-11-1a & La Rioja, Spain \\
\hline D. seriata & Y180-20-1 & La Rioja, Spain \\
\hline D. seriata & Y181-9-1 & Tierra de León, Spain \\
\hline D. seriata & Y181-13-1b & Tierra de León, Spain \\
\hline D. seriata & Y181-21-1 & Tierra de León, Spain \\
\hline D. seriata & Y213-8-2c & Córdoba, Spain \\
\hline D. seriata & Y221-14-3a & Rueda, Spain \\
\hline
\end{tabular}


(a) Continued.

\begin{tabular}{lcc}
\hline Species & Strain & Location \\
\hline D. seriata & ${ }^{*}$ V14-2a & Nursery, Spain \\
D. seriata & ${ }^{*}$ R21-1a & Nursery, Spain \\
\hline
\end{tabular}

(b)

\begin{tabular}{|c|c|c|}
\hline Species & Strain & Location \\
\hline Diplodia mutila & CBS431.82 & The Netherlands \\
\hline D. mutila & Y50-5-1c & Ribera del Duero, Spain \\
\hline D. mutila & Y50-7-2b & Ribera del Duero, Spain \\
\hline D. mutila & Y60-7-2a & Tierra de León, Spain \\
\hline D. mutila & Y63-1-1b & Arribes, Spain \\
\hline D. mutila & Y113-7-1 & Arribes, Spain \\
\hline D. mutila & Y117-10-1b & Arribes, Spain \\
\hline D. mutila & Y122-10-1 & Arribes, Spain \\
\hline D. mutila & Y167-9-1 & Alicante, Spain \\
\hline Neofusicoccum parvum & CBS110301a & Portugal \\
\hline N. parvum & INIA_352c & Madrid, Spain \\
\hline N.parvum & Y57-8-1b & Nursery, Spain \\
\hline N. parvum & Y91-3-1a & Nursery, Spain \\
\hline N. parvum & Y108-9-1 & Extremadura, Spain \\
\hline N. parvum & Y159-24-1 & $\begin{array}{l}\text { Castilla La Mancha, } \\
\text { Spain }\end{array}$ \\
\hline N. parvum & Y187-8-1 & Ribera del Duero, Spain \\
\hline Botryosphaeria dothidea & Sonoma_c & California, USA \\
\hline B. dothidea & CBS110302 & Portugal \\
\hline B. dothidea & Y264-19-1 & Nursery, Spain \\
\hline Dothiorella iberica & Y51-4-3a & Tierra de León, Spain \\
\hline D. iberica & Y81-1-2 & Ribera del Duero, Spain \\
\hline D. iberica & Y190-3-3 & Ribera del Duero, Spain \\
\hline Dothiorella sarmentorum & CBS120.41 & Norway \\
\hline D. sarmentorum & Y51-4-3b & Arribes, Spain \\
\hline D. sarmentorum & Y262-12-1 & Nursery, Spain \\
\hline Lasiodiplodiatheobromae & CBS110.11 & nd \\
\hline L. theobromae & Y512-03-1 & Nursery, Spain \\
\hline Neofusicoccum luteum & CBS110299 & Portugal \\
\hline Neofusicoccum australe & Y264-21-1 & Nursery, Spain \\
\hline $\begin{array}{l}\text { Phaeoacremonium } \\
\text { aleophilum }\end{array}$ & CBS631.94b & Italy \\
\hline P. aleophilum & Y082-02-5c & Toro, Spain \\
\hline $\begin{array}{l}\text { Phaeomoniella } \\
\text { chlamydospora }\end{array}$ & CBS101359 & Italy \\
\hline P. chlamydospora & Y170-03-1 & Alicante, Spain \\
\hline $\begin{array}{l}\text { Cylindrocarpon } \\
\text { macrodidymum }\end{array}$ & V049-01c & Nursery, Spain \\
\hline C. macrodidymum & Y266-10-1 & Nursery, Spain \\
\hline C. liriodendri & Y111-07-2c & Arribes, Spain \\
\hline C. liriodendri & Y262-27-1 & Nursery, Spain \\
\hline C. olidum & Y160-23-2 & $\begin{array}{l}\text { Castilla La Mancha, } \\
\text { Spain }\end{array}$ \\
\hline C. olidum & Y160-57-1a & $\begin{array}{c}\text { Castilla La Mancha, } \\
\text { Spain }\end{array}$ \\
\hline
\end{tabular}

(b) Continued.

\begin{tabular}{lcc}
\hline Species & Strain & Location \\
\hline C. olidum & Y264-22-1 & Nursery, Spain \\
C. pauciseptatum & S018-03-1 & Salamanca, Spain \\
C. pauciseptatum & S020-02-2 & Salamanca, Spain \\
Phomopsis viticola & Y529-07-1 & Nursery, Spain \\
P. viticola & Y264-17-1 & Nursery, Spain \\
Eutypa lata & Y249-4-4 & Toro, Spain \\
Fomitiporia & Y255-14-1 & Ribera del Duero, Spain \\
mediterranea & Y112-29-1 & Arribes, Spain \\
Stereum hirsutum & Y231-05-4 & Ribera del Duero, Spain \\
Cryptovalsa ampelina & Castilla La Mancha, \\
Cadophora luteoolivacea & Y160-56-2 & Spain \\
Fomitiporella coryophilli & Y234-11-2 & Rueda, Spain \\
D. coryli & Y291-24-1 & Tierra de León, Spain \\
Eutypella citricola & 810 & Barcelona, Spain \\
Fusarium oxysporum & Y239-1-5 & Rueda, Spain \\
Alternaria solani & CBS109157 & USA \\
Acremonium sp. & Y161-9-2 & Alicante, Spain \\
Epicoccum sp. & TP32-1C1 & Valladolid, Spain \\
Psathyrella sp. & Y266-4-1 & Nursery, Spain \\
\hline & & \\
\hline & &
\end{tabular}

Foster City, CA, USA) with the primers detailed below. After amplification, the total volume of the reaction of each PCR product was separated by electrophoresis in $1.5 \%$ agarose (low EEO, Conda Pronadisa, Madrid, Spain) gels in 1xTAE (Trisacetate-EDTA). After electrophoresis $\left(0.5 \mathrm{Vcm}^{-1}\right)$ the gels were stained with $0.5 \mu \mathrm{g} / \mathrm{mL}$ ethidium bromide, visualized, and photographed using a UV transilluminator. A preselection of the 20 OPERON primers (Operon Technologies, La Jolla, CA, USA) of the OPA, OPD, and OPE series was made using the DNA of 23 isolates of $D$. seriata, five isolates of D. mutila, three isolates of $N$. parvum, one isolate of $B$. dothidea, and one isolate of D. iberica. Primers allowed patterns with distinguishable and reproducible bands to be preselected. Then fragment size and proximity of other bands were additional criteria for selecting the most specific marker for D. seriata. Each RAPD marker was treated and analysed [17].

2.3.2. DNA Cloning. Eleven D. seriata isolates, Napa-c, CBS112555a, Y46-1-1b, Y62-1-1c, Y79-4-3a, Y90-10-1a, Y1034-3a, Y112-24-1a, Y116-10-1c, V14-2a, and R21-1a (Table 1(a)), were used for cloning assays. The selected isolates represented the combination of the most variable geographic origin from our collection and different grapevine ages and included both isolates from both cankers and asymptomatic plants. OPE-20 RAPD markers specific for each isolate were separated by electrophoresis on $1.5 \%$ of agarose gel (TAE) and the $1200 \mathrm{bp}$ fragment common to all D. seriata isolates was recovered, eluted, and purified using the commercial Kit GE Healthcare GFX PCR DNA and Gel Band Purification. DNA fragment was cloned by Sistemas 
Genómicos Agroalimentaria, Paterna, Spain. From each isolate five white/positive colonies of transformed Escherichia coli-DH5 $\alpha$ were sequenced. The sequences were then analysed using the CLUSTALW (http://www.ebi.ac.uk/) program and SCAR primers were designed on the basis of the obtained sequences using http://www.ncbi.nlm.nih.gov/tools/primerblast/.

\subsection{PCR Amplification Using the SCAR Primers}

2.4.1. PCR Specificity. The specificity of each primer pair was tested in amplification tests with purified and/or extracted DNA of 47 D. seriata isolates. Nontargeted DNAs of 57 isolates belonging to fungi associated with grapevine decline from our collection such as twelve Botryosphaeriaceae spp.: $D$. mutila, B. dothidea, L. theobromae, D. sarmentorum, D. iberica, D. viticola, D. coryli, N. parvum, N. australe, N. mediterraneum, N. luteum, and N. ribis, fourteen other fungi species: P. chlamydospora, Phaeoacremonium aleophilum, Cylindrocarpon macrodidymum, C. liriodendri, C. olidum, C. pauciseptatum, P. viticola, E. lata, Eutypella citricola, Cryptovalsa ampelina, Cadophora luteoolivacea, Fomitiporia mediterranea, Fomitiporella coryophilli, and Stereum hirsutum, isolates of other fungi belonging to the genera of Fusarium, Alternaria, Acremonium, Didymella, Phomopsis, Epicoccum, Psathyrella, Ceratobasidium, and Pestalotia, and Vitis vinifera cvs. Tempranillo and Viura were tested.

The PCR reaction mix was done following the commercial recommendation of Redextract-n-Amp plant PCR kit with the indicated modification: $4 \mu \mathrm{L}$ of the commercial mix, $0.4 \mu \mathrm{M}$ of each primer, and $1 \mu \mathrm{L}$ of template (purified or extracted DNA) in a final volume of $10 \mu \mathrm{L}$. PCR reactions were then carried out according to the following basic scheme: the reaction mix was denatured at $95^{\circ} \mathrm{C}$ for $5 \mathrm{~min}$, followed by $35 \mathrm{cycles}$ of $30 \mathrm{sec}$ at $94^{\circ} \mathrm{C}$ (denaturing), $45 \mathrm{sec}$ at the annealing temperature of $57^{\circ} \mathrm{C}$ for DS3.8 S3-DS3.8 R6 or at $60^{\circ} \mathrm{C}$ for DS3.8 S3-DS3.8 R4, $45 \mathrm{sec}$ at $72^{\circ} \mathrm{C}$ (extension), and a final extension phase of $7 \mathrm{~min}$ at $72^{\circ} \mathrm{C}$. After amplification, the PCR products were separated by electrophoresis in $1.5 \%$ agarose gels in 1xTBE (Tris-borate-EDTA). The gels were stained and visualised as described above.

2.4.2. PCR Sensitivity. The sensitivity of SCAR DS3.8 S3DS3.8 R6 and DS3.8 S3-DS3.8 R4 primers was ascertained in PCR reactions with D. seriata CBS719.85 and Y207-1-1c. Assays were performed as three independent experiments. The following dilutions of DNA were used as template: 1, 0.1, $0.01,10^{-3}, 10^{-4}$, and $10^{-5} \mathrm{ng} / \mu \mathrm{L}$. For these assays only purified DNA-DNeasy QIAGEN-was used.

2.4.3. D. seriata Detection in Infected Wood Samples. Twelve Vitis vinifera (cv. Tempranillo grafted onto 110R-rootstocks) vines were inoculated with each of the $D$. seriata isolates Y103-4-2a and Y207-1-1c. 00E4 Twelve control plants were inoculated with a sterile agar plug (PDA). For the inoculation a wound was produced in the trunk of the vine, and an agar plug containing or not an actively growing culture of each isolate was placed on the wound and covered with parafilm.
All grapevines were maintained in a greenhouse at $20-25^{\circ} \mathrm{C}$. After four months, the D. seriata was reisolated and identified. These fungi could be reisolated $1 \mathrm{~cm}$ over the inoculation point and incipient wood symptoms could be observed. The effectiveness of the inoculation was evaluated using the conventional method of fungi isolation [2], consisting of cutting six wood chips (approx. diam. 1-2 mm; approx. length $0.5-1 \mathrm{~cm}$ ) that were placed on malt extract agar platesMEA (Merck, Darmstadt, Germany), and incubated at $25^{\circ} \mathrm{C}$ in darkness until fungi grew to an extent that could be isolated and placed on PDA plates. As above PDA plates were incubated and grown colonies were morphologically and molecularly identified using the primers pair described in this study (DS3.8 S3-DS3.8 R6 and DS3.8 S3-DS3.8 R4). The inoculated plants used in this study correspond to plants in which the inoculated fungi were isolated and identified from the six wood chips placed on MEA. Three wood chips were cut from four control plants and from four plants infected with each isolate. DNA purification was performed with one chip of each grapevine using the QIAGEN kit as described above. The second chip from each was placed in a tube containing $1 \mathrm{~mL}$ of malt extract (ME) medium, and the third chip was incubated in $1 \mathrm{~mL}$ sterile water. After 2 days at $25^{\circ} \mathrm{C}$ in darkness, conventional PCR was performed under the conditions described above with $2 \mu \mathrm{L}$ of purified DNA, $2 \mu \mathrm{L}$ of the incubation $\mathrm{ME}$, or $2 \mu \mathrm{L}$ of the incubation water.

SCAR primers were validated under field conditions. Throughout field prospection eight samples of Vitis vinifera branches were excised from vines exhibiting black dead arm or Eutypa dieback symptoms. Seven samples were collected in Cigales and Toro (Spain) and one sample came from Portugal. Wood chips were excised from these naturally infected wood samples showing a dark area. Diplodia seriata was detected following the same procedure as described before for inoculated wood: fungi morphological identification, wood chip DNA purification, incubations, and PCR amplifications.

\section{Results}

Among the numerous species associated with grapevine decline, Botryosphaeriaceae spp. are the dominant with more than 540 isolates obtained from 381 samples. Molecular identification of 127 isolates of Botryosphaeriaceae using restriction patterns and ITS sequencing revealed that $65 \%$ of them were D. seriata. Diplodia mutila represented $6 \%$ and other species of Botryosphaeriaceae were identified in lesser percentages. All these methods are time-consuming, so, in order to improve the molecular identification, PCR specific primers were developed.

3.1. RAPD Analysis. The high resolution achieved with RAPD enabled the characterisation of intraspecific variation. In an initial screening, primers that provided reproducible patterns were selected; of the 20 primers in each of the OPA, OPD, and OPE kits, seven decamer primers were selected: OPA2, OPD-2, -8 , and -16, OPE-3, -19, and -20 to study singlespore cultures of the 23 selected $D$. seriata isolates, five $D$. mutila, three $N$. parvum, one B. dothidea, and one D. iberica 
TABLE 2: SCAR primer sequences used in this study for the conventional PCR detection of Diplodia seriata.

\begin{tabular}{lccc}
\hline Target & Name & Type & Sequence \\
\hline \multirow{2}{*}{ Fragment 3.8 } & DS3.8 S3 & Forward primer & $5^{\prime}$-ATCCTCATACTACGGCACGG-3' \\
& DS3.8 R4 & Reverse primer & $5^{\prime}$-CCGTAGTCTCCCCTTTCCTC-3' \\
& DS3.8 R6 & Reverse primer & $5^{\prime}$-AACGGTGACCCATTCCAC-3 \\
\hline
\end{tabular}

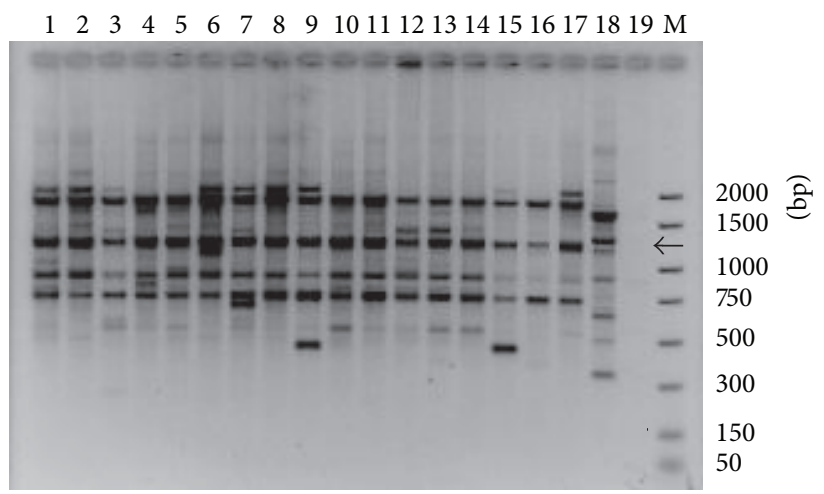

FIGURE 1: Random amplified polymorphic DNA of Diplodia seriata using primer OPE-20: amplified fragments were separated by 1.5\% agarose gel electrophoresis (TAE). Lanes 1 to 17 corresponding, respectively, to D. seriata isolates: V14-2a, Y79-4-3a, Y103-3-3b, CBS719.85, Y84-1-1a, Y221-14-3a, Y213-8-2c, Napa-c, CBS112555, Y62-1-1c, Y90-10-1a, Y46-1-1a, Y112-24-1a, Y128-3-1b, Y168-21-1b, Y181-13-1b, and Y178-11-1a; lane 18: D. mutila Y50-7-2b; and lane 19: $\mathrm{H}_{2} \mathrm{O}$. Lane M: DNA molecular weight marker; the fragment size is indicated on the right. RAPD marker OPE-1200 bp is indicated by an arrow.

and absence of DNA. Amplification with the selected primers provided 6-15 clear and reproducible bands. The product sizes obtained ranged from approximately 350 to $3000 \mathrm{bp}$. The combined results for the seven decamer RAPD primers produced 75 markers, generating ten genetically distinct groups of $D$. seriata isolates (data not shown) that indicated moderate genetic variation among the isolates studied in the present work.

Amplified products with OPE-20 generated four common fragments of about 1900, 1200, 960, and 795 bp and eight polymorphic fragments of about 2150, 1800, 1520, 1480, 1180, 870,615 , and $500 \mathrm{bp}$ for $D$. seriata. D. mutila isolate gave a different pattern of bands and no band was amplified in absence of DNA template (Figure 1). N. parvum, B. dothidea, and $D$. iberica gave also different patterns (data not shown).

3.2. PCR Amplification Using the SCAR Primers. Speciesspecific markers common to all assayed isolates of $D$. seriata were searched. The OPE20-1200 bp fragment present in $D$. seriata isolates (indicated by an arrow in Figure 1) was selected. The $1200 \mathrm{bp}$ fragment from eleven different $D$. seriata isolates (Table 1(a)) was cloned. Five positive colonies from each isolate were sequenced. Four fragments were obtained. A fragment (namely, DS3.8) of 1207 bp was selected. The sequence of the fragment DS3.8 was used to design five primers that were tested in five combinations. Each SCARprimer pair was tested in an amplification experiment to establish appropriate operative conditions using DNA of $D$. seriata, D. mutila, B. dothidea, N. parvum, L. theobromae, and D. sarmentorum species present in Castilla y León and
N. ribis. Afterwards three primers (DS3.8 S3 sense and DS3.8 R6 and DS3.8 R4 reverse) were selected and combined for conventional PCR: DS3.8 S3-DS3.8 R6 and DS3.8 S3-DS3.8 R4 producing $634 \mathrm{bp}$ and $233 \mathrm{bp}$ amplicons, respectively. Primer sequences are shown in Table 2. The experiments made it possible to select two primer pairs in the fragment DS3.8 which yielded the most reproducible results and a single band with strong fluorescence.

3.3. PCR Specificity. Both primer pairs produced a unique band of the expected size (634 bp and $233 \mathrm{bp}$ ) for $47 \mathrm{D}$. seriata isolates using Redextract-N-Amp plant PCR kit (Table 1(a)). No specific fragments were obtained with any of the 57 isolates of 28 species other than $D$. seriata obtained and identified from symptomatic and asymptomatic grapevines. No specific fragments were obtained when Vitis vinifera was used as the DNA template. Figure 2(a) showed the result of PCR amplification using DS3.8 S3-DS3.8 R4 primers with DNA of nine D. seriata isolates and nine DNA of other species (D. mutila, N. parvum, B. dothidea, L. theobromae, D. sarmentorum, D. iberica, $N$. luteum, $P$. chlamydospora, and $P$. aleophilum). Figure 2(b) showed the result of PCR amplification using DS3.8 S3-DS3.8 R6 primers with DNA of the same isolates as before.

The specificity of the reaction was implemented using the DNA from other fungal species together (D. mutila, N. parvum, D. sarmentorum, $P$. aleophilum, P. chlamydospora, $C$. pauciseptatum, and Alternaria sp.) and the DNA of D. seriata: CBS719.85. The PCR conditions established for each primer pair produced only the expected amplicon (data not shown). 


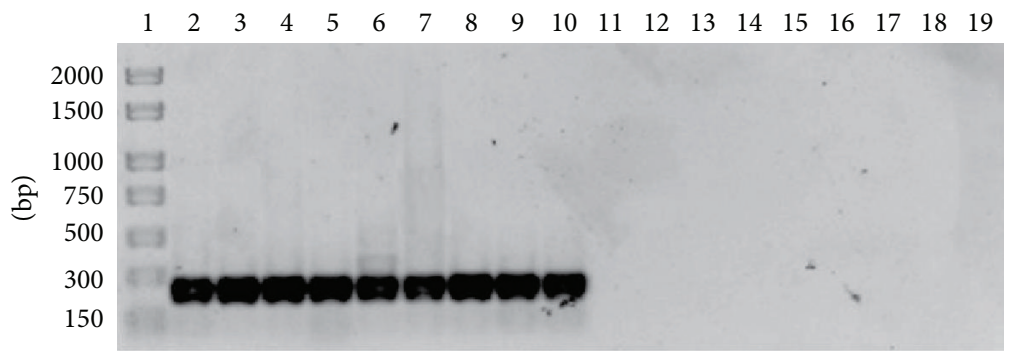

(a)

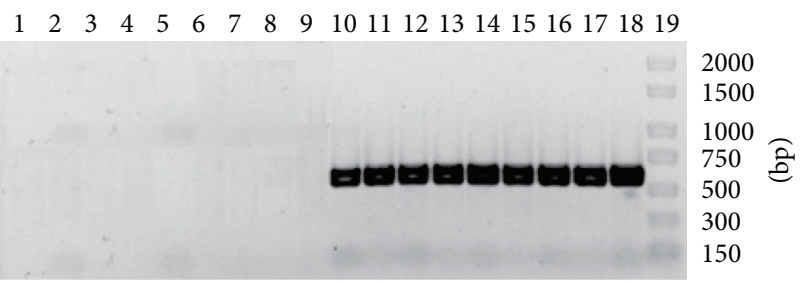

(b)

FIGURE 2: SCAR primers specificity. The amplified fragments were separated by $1.5 \%$ agarose gel electrophoresis (TBE). (a) The PCR amplifications were carried out using the primer pair DS3.8 S3-DS3.8 R4 yielding 233 bp amplicon. Lane 1: DNA molecular weight marker; the fragment size is indicated on the right. Lanes 2 to 10 corresponding, respectively, to D. seriata isolates: CBS719.85c, R21-1a, Y46-8-1b, Y63-4-1b, Y87-3-1c, Y111-27-1, Y116-27-96, Y121-15-4, and Y125-12-1b. Lanes 11 to 19 corresponding, respectively, to controls DNA of others species: D. mutila Y128-10-1, N. parvum Y159-24-1, B. dothidea CBS110302, L. theobromae CBS110.11, D. sarmentorum CBS120.41, D. iberica Y81-1-2, N. luteum CBS110299, P. chlamydospora CBS101359, and P. aleophilum CBS631.94b. (b) DS3.8 S3-DS3.8 R6 yielding 634 bp fragment. Lanes 1 to 9 corresponding, respectively, to controls DNA of others species: D. mutila Y128-10-1, N. parvum Y159-24-1, B. dothidea CBS110302, L. theobromae CBS110.11, D. sarmentorum CBS120.41, D. iberica Y81-1-2, N. luteum CBS110299, P. chlamydospora CBS101359, and P. aleophilum CBS631.94b. Lanes 10 to 18 corresponding, respectively, to D. seriata isolates: CBS719.85c, R21-1a, Y46-8-1b, Y63-4-1b, Y87-3-1c, Y111-27-1, Y11627-96, Y121-15-4, and Y125-12-1b. Lane 19: DNA molecular weight marker; the fragment size is indicated on the left.

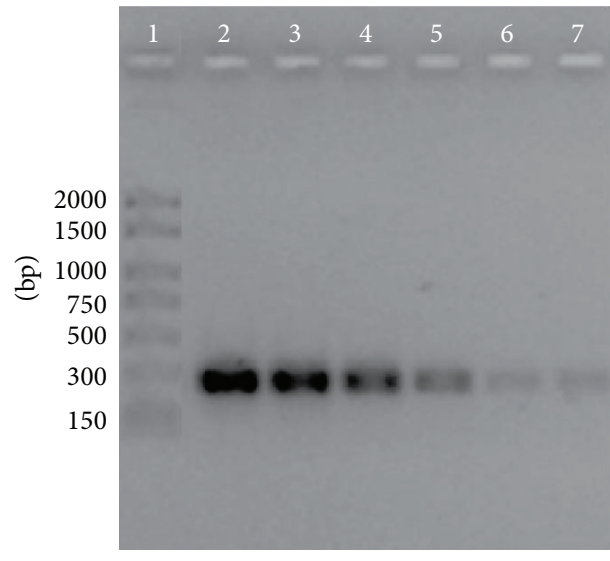

(a)

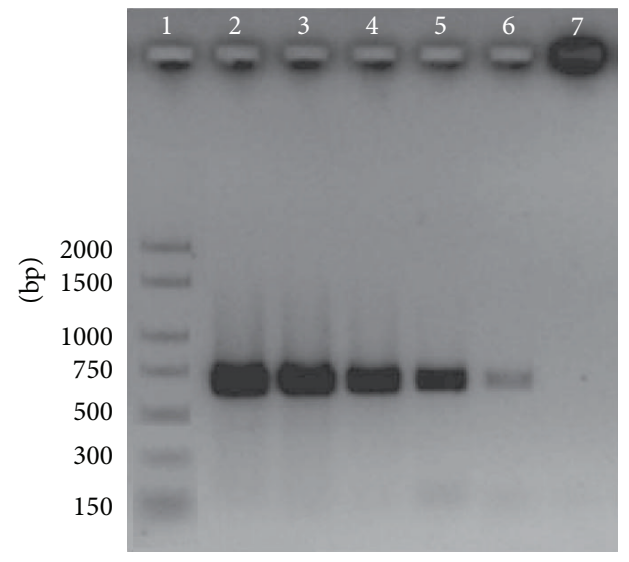

(b)

FIGURE 3: SCAR primers sensitivity. The amplified fragments were separated by $1.5 \%$ agarose gel electrophoresis (TBE). (a) The PCR amplifications were carried out using the primer pair DS3.8 S3-DS3.8 R4 yielding 233 bp fragment. (b) DS3.8 S3-DS3.8 R6 yielding 634 bp amplicon. Lane 1: DNA molecular weight marker; the fragment size is indicated on the right. Lanes 2 to 7 corresponding to D. seriata CBS719.85 as a template tested at decreasing concentrations: $1,0.1,0.01,10^{-3}, 10^{-4}$, and $10^{-5} \mathrm{ng} / \mu \mathrm{L}$, respectively.

3.4. PCR Sensitivity. The PCR efficiency for each primer pair was assayed with $D$. seriata purified genomic DNA. The 10fold serial dilutions from genomic DNA were prepared from concentrated samples to obtain a broad range of dilutions $\left(1,0.1,0.01,10^{-3}, 10^{-4}\right.$, and $\left.10^{-5} \mathrm{ng} / \mu \mathrm{L}\right)$. Each dilution was analyzed in triplicate with two different isolates. The serial dilutions of CBS719.85 genomic DNA were represented in Figure 3(a) using DS3.8 S3-DS3.8 R4 primers and Figure 3(b) with DS3.8 S3-DS3.8 R6 primers. A clear band remained visible in lane 5 for primers combination DS3.8 S3-R4 
TABLE 3: Detection of Diplodia seriata in wood chips.

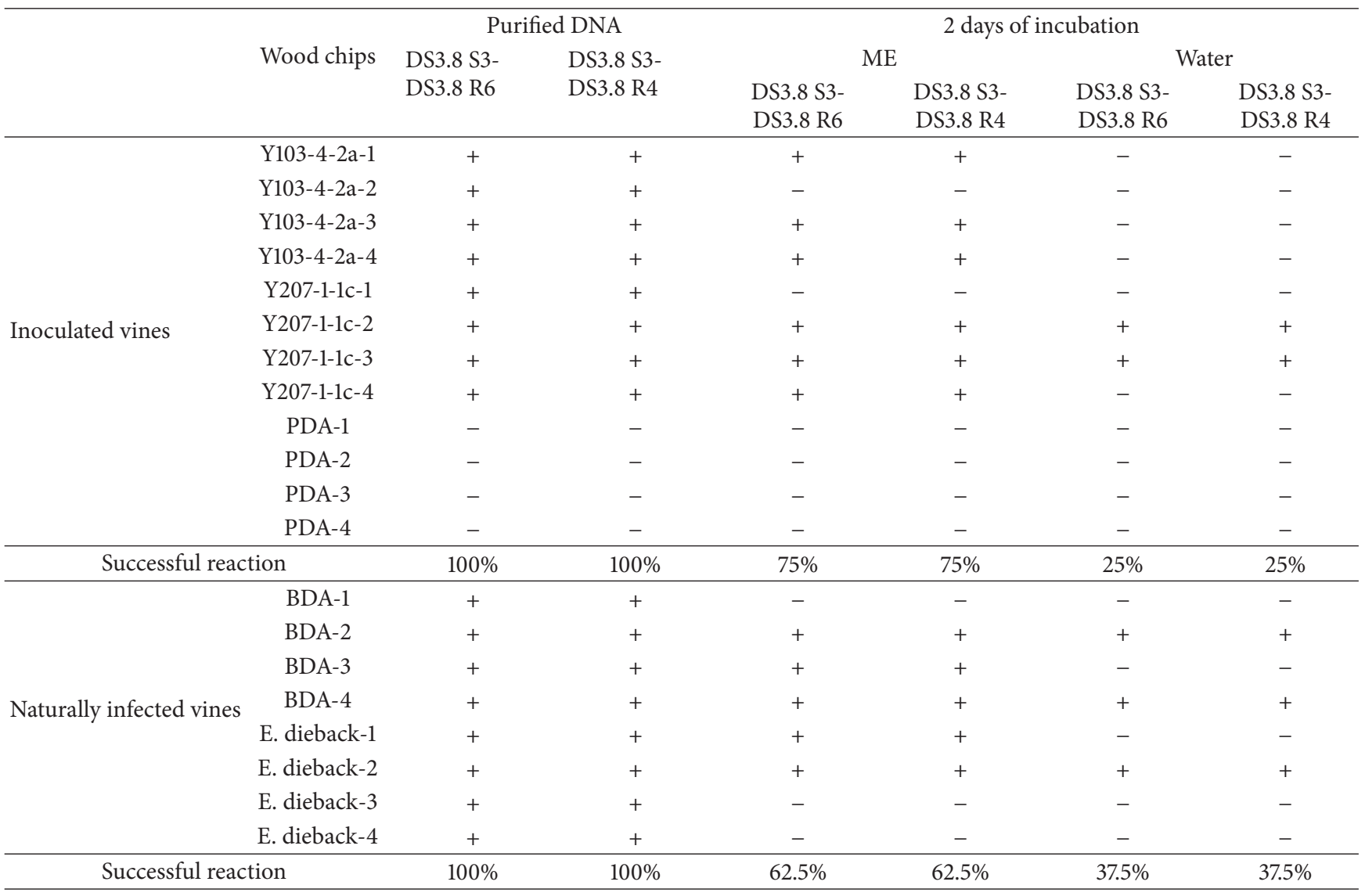

BDA: black dead arm; E. dieback: Eutypa dieback. +: positive amplification of the expected fragment, with DS3.8 S3-DS3.8 R6 (634 bp) and with DS3.8 S3DS3.8 R4 (233 bp). -: no amplification.

(233 bp) and in line 6 for primer combination DS3.8 S3-R6 (634 bp), establishing the detection limits in $1 \mathrm{pg}$ and $0.1 \mathrm{pg}$ of DNA, respectively.

3.5. Detection of D. seriata in Wood Samples. DNA purified from wood chips obtained from naturally infected grapevines or from grapevines inoculated with two different $D$. seriata isolates showed the expected $634 \mathrm{bp}$ and $233 \mathrm{bp}$ fragments using DS3.8 S3-DS3.8 R6 and DS3.8 S3-DS3.8 R4, respectively, for all samples. No amplification was observed with wood inoculated with a PDA plug containing no mycelium (Table 3 ). These results confirmed the above identification done using conventional methods consisting of the culturing of six wood chips in culture medium for each inoculated plant and morphological identification of the isolated fungi. Positive amplification of D. seriata in $62.5 \%$ to $75 \%$ of reactions was obtained with wood chips incubated for 2 days in culture medium with no DNA purification (Table 3). Field samples showing BDA and Eutypa dieback symptoms as well as grapevines inoculated with the Y103-4-2a or with Y207-11c isolate returned $634 \mathrm{bp}$ and $233 \mathrm{bp}$ fragments using DS3.8 S3-DS3.8 R6 and DS3.8 S3-DS3.8 R4, respectively. A positive reaction was found with three samples for each isolate and BDA symptoms and with two samples of plant showing
Eutypa dieback. When incubation was performed in water for 2 days, the amplification result was lower (positive detection in $25 \%$ to $37.5 \%$ of reactions).

\section{Discussion}

Morphological identification of Botryosphaeriaceae spp. requires the work of specialists and time until the isolates produce spores that not always allow for the discrimination between genera and/or species. Based on the mycelium aspect, colour and growth on PDA medium 540 isolates from our collection were assigned as different species of the family Botryosphaeriaceae. Spores morphology helps in Botryosphaeriaceae spp. identification. However, nowadays molecular methods facilitate fungi identification. Sequencing and other molecular biology and PCR methods improve fungi identification, as well as studies of epidemiology and phylogeny. The development of restriction digest patterns following PCR amplification of the rDNA region has permitted the identification of some Botryosphaeriaceae spp. [9]. ITS sequence of $D$. seriata allowed the differentiation among different Botryosphaeriaceae spp. [9, 18-20]. However, it has not been possible to apply ITS alone to identify a Botryosphaeriaceae sp. Elongation factor 1-alpha and beta tubulin 
genes sequences allowed molecular differentiation among Botryosphaeriaceae spp. [21]. Restriction enzymes analyses and sequencing require manipulating the amplified products and increase the risk of contamination. Moreover they are time-consuming and more expensive than a conventional PCR with specific primers that reduce the identification steps in a single reaction.

Using restriction enzymes analyses and ITS sequencing methods the identification of 127 isolates of our collection was confirmed; $65 \%$ of them belong to $D$. seriata species. Preliminary RAPD enabled the characterisation of intraspecific variation of the most abundant Botryosphaeriaceae spp. found in Castilla y León grapevines. Taking into account all this information for the confirmation of the identification of the remaining isolates of our collection, SCAR primers were designed following the indication found in [10-14]. An OPE20 RAPD fragment of around $1200 \mathrm{bp}$ was present in all $D$. seriata isolates and absent in the tested samples of D. mutila, N. parvum, B. dothidea, or D. iberica, so it was cloned. Among the cloned fragments a fragment of $1207 \mathrm{bp}$ was selected and three primers allowed two combinations for conventional PCR. SCAR primers are available for easier identification of $D$. seriata.

The primers specificity was ascertained with the positive amplification of 47 isolates of $D$. seriata and the absence of specific fragments amplification with 57 isolates belonging to 28 different species. The sensitivity of the two PCR established the limit of $D$. seriata detection between 1 and $0.1 \mathrm{pg} / \mu \mathrm{L}$ DNA. The sensitivity of SCAR primers published by Pollastro et al. [14] produced specific band with $0.1-1$ ng of the target DNA. The PCR system described here improves and facilitates $D$. seriata identification. The easy and rapid detection of $D$. seriata will be an important advantage to guarantee the pathogen-free status of the propagated material in grapevine nurseries. The diagnostic methods described here improve previous techniques. To facilitate the diagnosis and taking into account our previous publication (Martín et al. [22]), wood chip samples were incubated in liquids. These liquids were then used as the DNA template in the PCR. Diplodia seriata PCR provided positive signals in $62.5 \%$ to $75 \%$ and $25 \%$ to $37.5 \%$ of the samples incubated in culture medium and water, respectively. To our knowledge, this is the first report of the use of conventional PCR for D. seriata detection in incubation liquid without DNA extraction and without a fungal isolation procedure. All isolates were $100 \%$ detected in wood chips after DNA purification by PCR and conventional isolation methods. More investigation is required to confirm these results. Detection of $D$. seriata without the need for fungal isolation reduces the analysis times to two days and reduces associated costs.

\section{Conclusions}

Two primer pairs named DS3.8 S3-DS3.8 R6 and DS3.8 S3DS3.8 R4 were designed to perform a specific amplification of the pathogen D. seriata, one of the most common fungal species associated with grapevine decline. A single product of $634 \mathrm{bp}$ and $233 \mathrm{bp}$, respectively, was obtained for D. seriata isolates but never from DNA of other 28 fungal species.
A high sensitivity of the SCAR primers designed was found. These two conventional PCR were demonstrated to be useful in the specific detection of $D$. seriata on naturally and artificially infected grapevine wood without fungal isolation. Therefore a new simple, cheap, rapid, and specific diagnostic tool has been described for D. seriata. Moreover, the results of this study can be applied to other woody hosts for which this fungus has been reported as a pathogen.

\section{Conflict of Interests}

The authors declare that there is no conflict of interests regarding the publication of this paper.

\section{Acknowledgments}

This work was funded by the Instituto Nacional de Investigación y Tecnología Agraria y Alimentarias (INIA RTA200707) and by FEDER and CE funds. Laura Martin was supported by Programa Personal Técnico de Apoyo, Ministerio de Educación y Ciencia (PTA-2003-01-01001), and Maria Teresa Martin was supported by Contratos Doctores Sistema INIA-CCAA (37, DR07-0161).

\section{References}

[1] S. Savocchia, C. C. Steel, B. J. Stodart, and A. Somers, "Pathogenicity of Botryosphaeria species isolated from declining grapevines in sub tropical regions of Eastern Australia," Vitis, vol. 46, no. 1, pp. 27-32, 2007.

[2] M. T. Martin and R. Cobos, "Identification of fungi associated with grapevine decline in Castillo y León (Spain)," Phytopathologia Mediterranea, vol. 46, no. 1, pp. 18-25, 2007.

[3] J. R. Úrbez-Torres, P. Adams, J. Kamas, and W. D. Gubler, "Identification, incidence, and pathogenicity of fungal species associated with grapevine dieback in Texas," The American Journal of Enology and Viticulture, vol. 60, no. 4, pp. 497-507, 2009.

[4] J. M. van Niekerk, P. W. Crous, J. Z. Groenewald, P. H. Fourie, and F. Halleen, "DNA phylogeny, morphology and pathogenicity of Botryosphaeria species on grapevines," Mycologia, vol. 96, no. 4, pp. 781-798, 2004.

[5] A. Taylor, G. E. S. J. Hardy, P. Wood, and T. Burgess, "Identification and pathogenicity of Botryosphaeria species associated with grapevine decline in Western Australia," Australasian Plant Pathology, vol. 34, no. 2, pp. 187-195, 2005.

[6] P. W. Crous, B. Slippers, M. J. Wingfield et al., "Phylogenetic lineages in the Botryosphaeriaceae," Studies in Mycology, vol. 55, pp. 235-253, 2006.

[7] A. J. L. Phillips, P. W. Crous, and A. Alves, "Diplodia seriata, the anamorph of "Botryosphaeria" obtusa," Fungal Diversity, vol. 25, pp. 141-155, 2007.

[8] J. de Wet, B. Slippers, O. Preisig, B. D. Wingfield, and M. J. Wingfield, "Phylogeny of the Botryosphaeriaceae reveals patterns of host association," Molecular Phylogenetics and Evolution, vol. 46, no. 1, pp. 116-126, 2008.

[9] A. Alves, A. J. L. Phillips, I. Henriques, and A. Correia, "Evaluation of amplified ribosomal DNA restriction analysis as a method for the identification of Botryosphaeria species," FEMS Microbiology Letters, vol. 245, no. 2, pp. 221-229, 2005. 
[10] J. M. McDermott, U. Brändle, F. Dutly et al., "Genetic variation in powdery mildew of barley: development of RAPD, SCAR, and VNTR markers," Phytopathology, vol. 84, no. 11, pp. 13161321, 1994.

[11] C. Délye and M.-F. Corio-Costet, "Origin of primary infections of grape by Uncinula necator: RAPD analysis discriminates two biotypes," Mycological Research, vol. 102, no. 3, pp. 283-288, 1998.

[12] I. Gell, J. Cubero, and P. Melgarejo, "Two different PCR approaches for universal diagnosis of brown rot and identification of Monilinia spp. in stone fruit trees," Journal of Applied Microbiology, vol. 103, no. 6, pp. 2629-2637, 2007.

[13] S. H. Lim, J. G. Kim, and H. W. Kang, "Novel SCAR primers for specific and sensitive detection of Agrobacterium vitis strains," Microbiological Research, vol. 164, no. 4, pp. 451-460, 2009.

[14] S. Pollastro, C. Dongiovanni, A. Abbatecola, M. A. de Guido, R. M. de Miccolis Angelini, and F. Faretra, "Specific SCAR primers for fungi associated with wood decay of grapevine," Phytopathologia Mediterranea, vol. 40, no. 3, pp. 362-368, 2001.

[15] R. Lardner, B. E. Stummer, M. R. Sosnowski, and E. S. Scott, "Molecular identification and detection of Eutypa lata in grapevine," Mycological Research, vol. 109, no. 7, pp. 799-808, 2005.

[16] L. Martín, L. E. Sáenz de Miera, and M. T. Martín, "AFLP and RAPD characterization of Phaeoacremonium aleophilum associated with Vitis vinifera decline in Spain," Journal of Phytopathology, vol. 162, no. 4, pp. 245-257, 2014.

[17] R. Cobos and M. T. Martin, "Molecular characterisation of Phaeomoniella chlamydospora isolated from grapevines in Castilla y León (Spain)," Phytopathologia Mediterranea, vol. 47, no. 1, pp. 20-27, 2008.

[18] S. Denman, P. W. Crous, J. E. Taylor, J. Kang, I. Pascoe, and M. J. Wingfield, "An overview of the taxonomic history of Botryosphaeria, and a re-evaluation of its anamorphs based on morphology and ITS rDNa phylogeny," Studies in Mycology, vol. 45, pp. 129-140, 2000.

[19] S. Denman, P. W. Crous, J. Z. Groenewald, B. Slippers, B. D. Wingfield, and M. J. Wingfield, "Circumscription of Botryosphaeria species associated with Proteaceae based on morphology and DNA sequence data," Mycologia, vol. 95, no. 2, pp. 294307, 2003.

[20] P. A. Barber, T. J. Burgess, G. E. S. J. Hardy, B. Slippers, P. J. Keane, and M. J. Wingfield, "Botryosphaeria species from Eucalyptus in Australia are pleoanamorphic, producing Dichomera synanamorphs in culture," Mycological Research, vol. 109, no. 12, pp. 1347-1363, 2005.

[21] J.-K. Liu, R. Phookamsak, M. Doilom et al., "Towards a natural classification of Botryosphaeriales," Fungal Diversity, vol. 57, no. 1, pp. 149-210, 2012.

[22] M. T. Martín, R. Cobos, L. Martín, and L. López-Enríquez, "Real-Time PCR Detection of Phaeomoniella chlamydospora and Phaeoacremonium aleophilum," Applied and Environmental Microbiology, vol. 78, no. 11, pp. 3985-3991, 2012. 

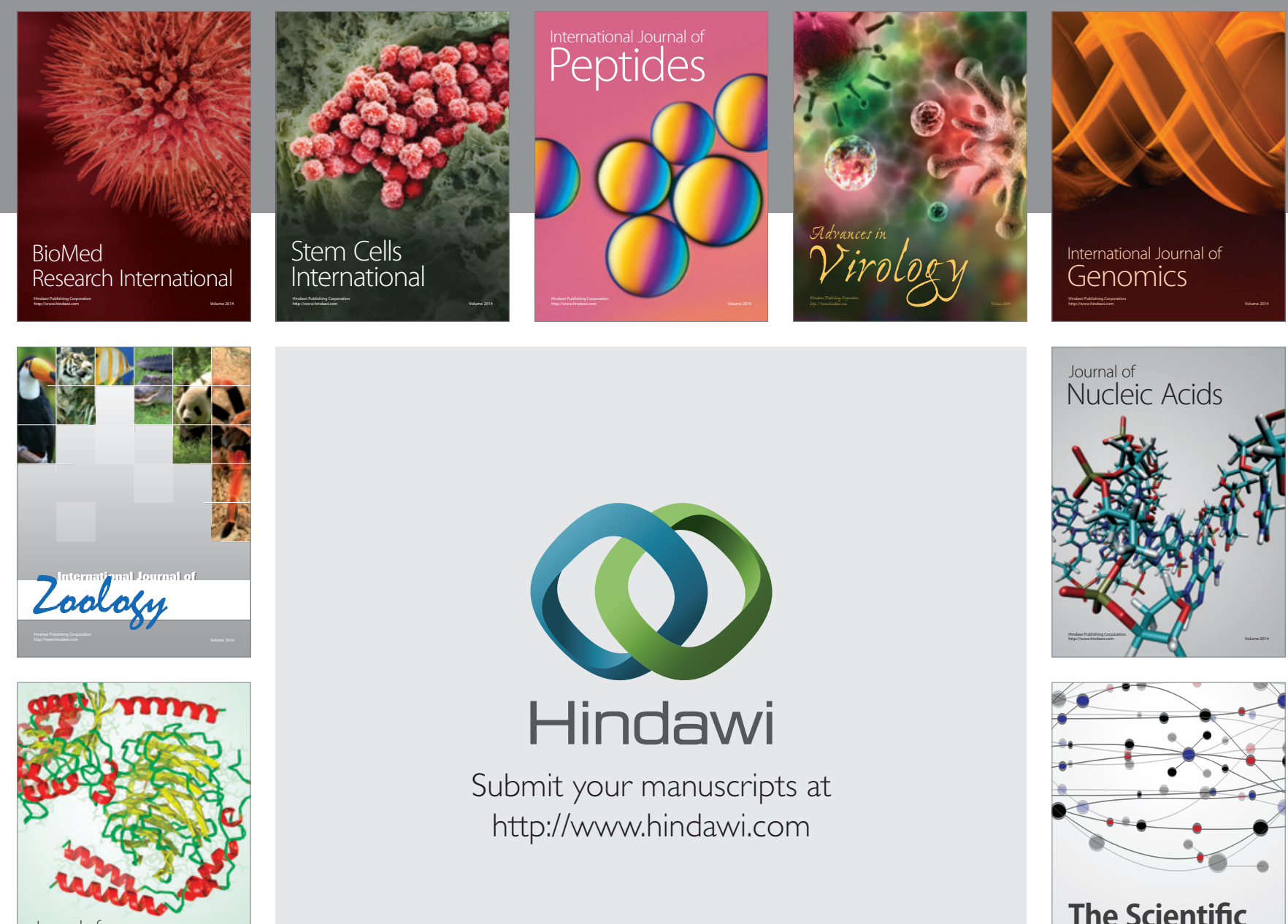

Submit your manuscripts at

http://www.hindawi.com

Journal of
Signal Transduction
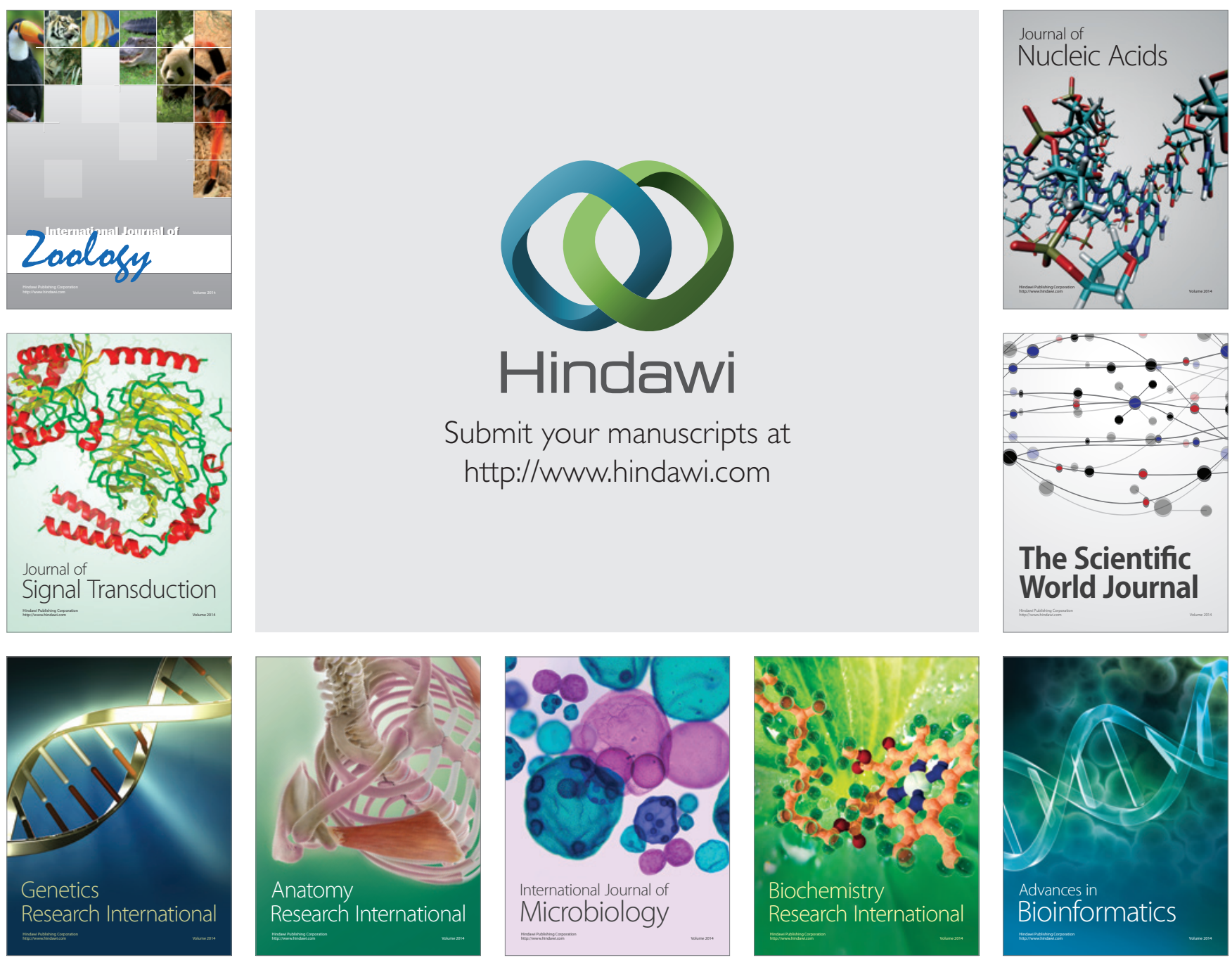

The Scientific World Journal
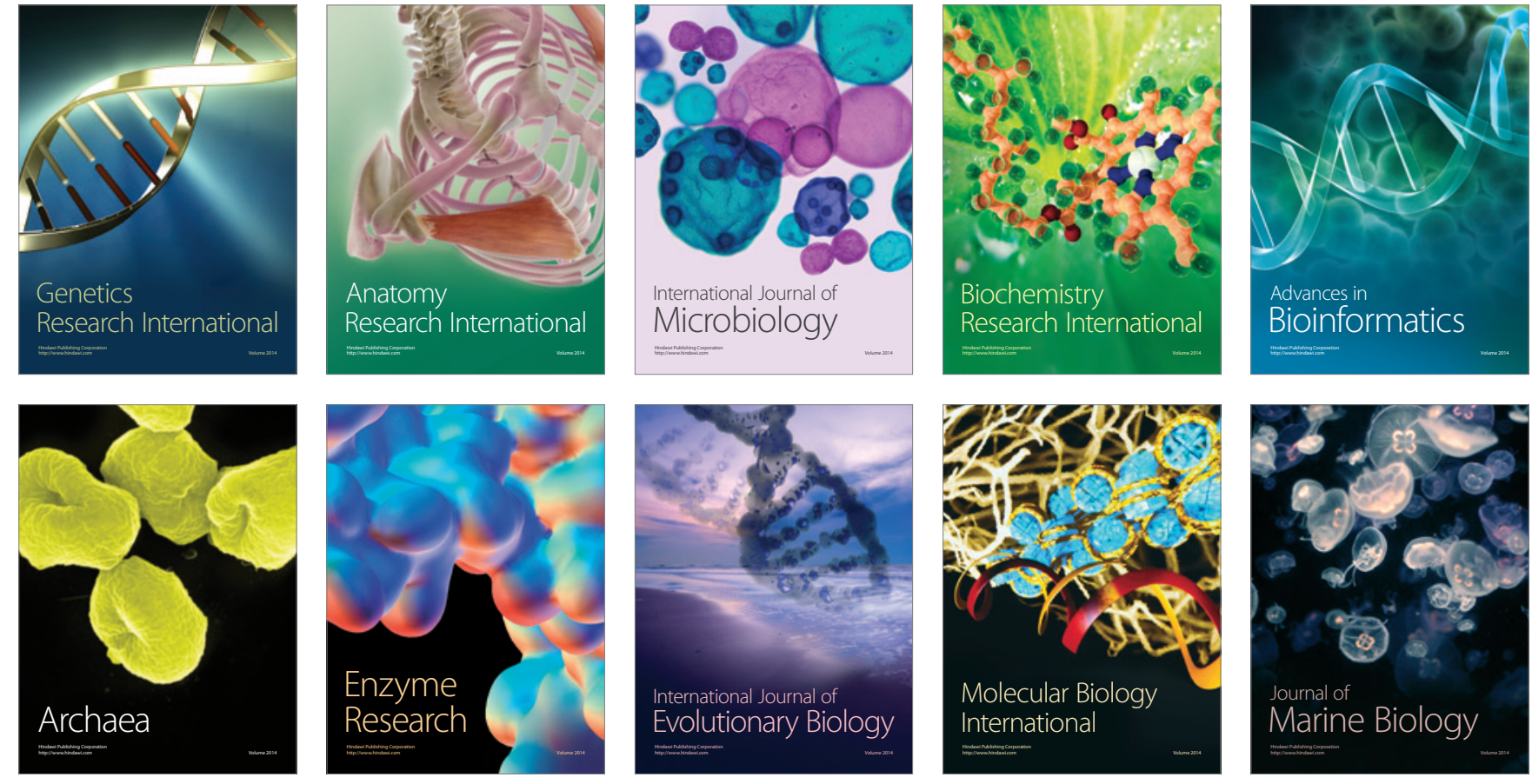